\title{
LIMITATIONS OF MUNICIPAL OWNERSHIP IN PENNSYIVANIA.
}

In view of the growth of public sentiment in this state in favor of municipal ownership of street railways, water, gas and electric light plants, a review of the powers of municipalities in this regard as conferred by the Acts of Assembly, and as defined by the Supreme Court, may be of service.

I. As to Street Passenger Railways. There is no Act of Assembly which confers upon any city or borough of this commonwealth the power either to construct such a railway or to purchase the lines of an existing company. Although the power exists in the legislature, under Section 3 of Article $\mathrm{XVI}$ of the Constitution, to take the property and franchises of incorporated companies and subject them to public use, yet it has never been exercised. with regard to street railway companies.

II. As to Water Companies. The powers of municipalities in this state to construct their own water works may be divided into four classes :

(a.) The powers of cities of the first class. These appear to be conferred by the Act of April I I, 1866, P. L. 635, authorizing the city of Philadelphia to purchase and hold in fee simple any springs of water or water privileges situated in any one or more of the counties adjoining the city and county of Philadelphia, and to construct thereon water works, reservoirs, etc., for the purpose of supplying water to the inhabitants of the city; by the Act of March 22, I870, P. L. 513 , authorizing the city of Philadelphia to become the purchaser of the franchises and property of any water company within its limits; and by the further Act of April 10, 1873, P. L. 636, whereby the city of Philadelphia is authorized to furnish water to the residents of the township of Springfield in Montgomery County. It is unnecessary to give in detail the extent to which the city of Philadelphia has availed itself of the powers conferred by these Acts; the only matter of interest connected therewith being the power of the city to increase its indebted- 
ness by the issue of bonds for the purpose of further increasing and improving its water supply, which question will be referred to later on.

(b.) The powiers of citics of the second class. These would seen to be conferred by the Acts of March 7, I 843 , P. L. 46 ; April 6, 1867, P. L. 85 I ; May I5, I 87 I, P. L. 368 ; March 18, 1873 , P. L. 302; May 2, 1879, P. L. 46 and May 25, I 887 , P. L. 267 . The first five of these Acts, in substance, confer upon the city of Pittsburg (the city of Alleghany having been a city of the third class until I 895 , and therefore eoming under that category) the power to construct water works, reservoirs and all necessary buildings and machinery and to lay water pipes for the supply of the inhabitants of the city; and also to contract with any neighboring city or borough for supplying its inhabitants with water, and for that purpose to appropriate water supplies within or without the limits of the city, and also to take water from the Alleghany or any other river for that purpose.

The Act of May 25, I887, P. L. 267, further authorizes any city desiring to erect water works or improve its water supply, to appropriate streams, lands, easements and rights of way, whether within its territorial limits or not, and to lay pipes therefrom across any lands, rivers, etc., upon payment of proper compensation to property owners.

In so far as the powers conferred by these Acts have not already been excrcised they would in all probability, wherever in conflict with exclusive rights confered upon private water companies, come within the rule of the Supreme Court defining similar powers of cities of the third class and boroughs where the same conflict with the rights of private water companic:s, which subject is discussed hereafter.

(c.) Thi powors of cities of the third class. These may agrain be sub-divided:

I. Into those which were conferred and put into operation by such cities while still boroughs, under the general borough law of April 3, 185 I, P. L. 320: or under their special charters, an enumeration of which is unnecessary: and

2. Into those which were conferred by the Municipal Act 
of May 23, I874, P. L. 230, known as the "Wallace Law," the provisions of which were substantially re-enacted by the Municipal Act of May 23, 1889, P. L. 277, relating to cities of the third class.

By these municipal Acts cities of the third class were given the exclusive right at all times to supply each city and its inhabitants with water, and for that purpose to either erect and maintain the necessary works, machinery, etc., or to make contracts. with any person or company for furnishing water for any length of time not excesding ten years; and the further power was also conferred of purchasing the plant of any water company already in existence in such city, or adjacent thereto, upon payment of the proper compensation.

These powers have recently been construed by the Supreme Court in the case of White v. The City of Mieadville, $177 \mathrm{~Pa}$. 643 (1895). This case arose as follows: The city of Meadville under its special charter possessed the same power of supplying water for the use of its inhabitants as was conferred upon it when a borough, by the general borough law of $185 \mathrm{I}$. In I 874 the city contracted with the Meadville Water Company for a supply of water for a period of ten years with the privilege of renewal for a further period of ten years. In 1891 the city accepted the provisions of the Act of May 23, 1874 . P. L. 230, known as the "Wallace Law," which acceptance brought it also within the purview of the Act of May 23, 1989, P. L. 277, which is the Act under which cities of the third class are now governed. In 1894 a municipal election was ordered for the purpose of increasing the debt for the construction of municipal water works. A bill in equity was filed by citizens of Meadville to restrain the construction of the water works. The Supreme Court, after careful consideration of all the questions involved, decided as follows :

a. That the Act of May 23, 1874, P. L. 230, known as the "Wallace Law," did not repeal the Act of April 29, 1874, P. L. 73, known as the General Corporation Act, and thercfore the city acquired no greater power under the. "Wallace Law" than it possessed under its prior charter. 
b. That the city having entered into a contract with the water company and permitted it to lay its pipes, the municipal function of supplying the city with water had passed from the city, and that it could not subsequently erect its own water works. That the legislature had conferred upon the municipality the power to supply itself and its inhabitants with water in two distinct ways; either by erecting its own plant or by contracting with a private company, either of which methods might be adopted, but that there was no grant of power to put both methods in operation at the same time; and that having elected to contract with the water company, such company acquired contract rights which could not be abrogated at the will of the municipality.

c. That at the end of twenty years if the city desired to supply its citizens with water it could do so, but only by purchasing the works of the company in the mode pointed out by the Act.

The effect of this decision is very sweeping, and although there may be exceptions depending upon the particular facts arising in some cities, yet there are very few cities of the third class which have not heretofore exercised their power of supplying water by contracting with a private water company, and it would seem, therefore, that no such city has any longer the right to erect its own plant without first purchasing the plant of the existing company.

One feature of the Acts of 1874 and 1889 , however, does not seem to have been touched upon in this decision, namely, that the power of the city to contract for a water supply is limited to ten years. If the city cannot at the end of such contract erect its own plant, and the twenty years have not expired so as to enable it to purchase the plant of a private company, then nothing remains for the city but to renew the contract for another term of years, and perhaps if this feature should hereafter be brought to the attention of the Supreme Court it might modify its conclusions in the Meadville case; although in the case of Wilson v. Rochestcr Borough, I So Pa. 509 (I 897), discussed hereafter, the contract between the borough and the water company had already expired, and yet 
the Supreme Court denied the right of the borough to construct its own plant.

(d.) The powers of boroughs. These, with rare exceptions, depending upon special charters, ase defined by the general borough law of $185 \mathrm{I}$, P. L. 320 , which authorizes boroughs "to provide a supply of water for the use of the inhabitants," under which power boroughs may not only erect their own water works, but contract with water companies for the supply of water to the borough ; and by the further Acts of April I6, I 875 , P. L. 55 ; June IO, I885, P. L. 81 ; and June 16 , I89I, P. L. 302 .

The Act of 1875 , as amended by the Act of 1891 , authorizes the levy of an additional tax for the purpose of erecting and purchasing such fire plugs, hydrants, gas or electric lamps, etc., as may be required to supply any borough with a sufficient supply of water for public purposes, and for properly lighting the streets, alleys, etc. (Section 2 of this Act, however, contains a proviso that before any borough shall exercise any of the powers conferred thereby the Act shall be approved of and accepted by the town council. Qucere, Does such proviso bring the Act within the case of the Appeal of the City of Scranton, $\mathrm{I}_{3} \mathrm{~Pa}$. I76, as being local legislation forbidden by Section 7 of Article III. of the Constitution?)

The Act of I 885 authorizes boroughs to supply and make contracts for "supplying water for ordinary and domestic uses to the inhabitants of a borough."

The Supreme Court has been called upon several times to define the powers of boroughs to erect their own water works under these Acts of Assembly, where such erection would interfere with the exclusive privileges of private water companies already in existence, and the decisions of that court have dealt a severe blow at municipal ownership. These decisions are as follows:

a. By the case of the Lchigh Water Co.'s Appeal, Io2 Pa. 515 ( 1883 ), it is apparently decided that the exclusive privilege vested in any private water company is exclusive only as to other private companies, and not as against municipalities; but an examination of the facts of that case shows that in 1867 
the borough of Easton was authorized by a special Act of Assembly to construct its own water works, provided a majority of the qualified voters of the borough were in favor of such construction. The Lehigh Water Company was incorporated in I 860, succeeding to the rights of the Easton Water Companyand the West Ward Water Company. None of the Acts relating to these companies conferred exclusive privileges upon them, therefore the legislature had the right in 1867 to confer upon the borough the right to construct its own water work', and such special Act was not repealed by the Act of April 29, I 874, P. L. 73, known as the General Corporation Act. The Lehigh Water Company therefore by accepting the exclusive privileges conferred by the Act of April 29, I874, on June 21, I 880 , could not by such acceptance abrogate the rights vested in the borough by the Act of 1867 , although such rights were not exercised until I $88 \mathrm{I}$. These facts are cited in the subscquent case of White v. City of Meadville, I77 Pa. 643, as distinguishing the Lehigh case from the Meadville and other. cases.

b. In How'ard's Appeal, I62 Pa. 374 (1894), it was held, relying upon the Leligh case, that the right of a borough to ercet water works was cntirely independent of the right of private corporations to erect similiar works. But this case is expressly overruled in the case of Whitc v. Mcadville, supra, where the right of a private company under its contract with a municipality was held to be a bar to the eiection of water works by such municipality.

c. In the case of The Gas and IVatcr Company' v. Dozuningtozen. $175 \mathrm{~Pa} .341$ (I 896 ), it was held that the legislaturc has the power to take away the right of a borough under the borough law of 1851 , to construct its own water works, and may exercise such power by conferring upon a private corporation the powcr previous!y conferred upon the borough, and, therefore. the Downingtown Water Company having by its charter granted in 1867 , the exclusive privilege of supplying the borough with water, such privilege could not be impaired by the construction of a municipa! plant.

d. In the case of Iletsgir v. Bcaier Falls Borough, i 78 Pa. 
I (I B95), the Supreme Court went a step further, and held that a water company organized under the General Corporation Act of April 29, 1874, by which Act exclusive privileges were conferred, and having a pending contract with the borough to supply water for fire and other purposes, is entitled to the exercise of such exclusive privileges until the expiration of twenty years from the date of its charter, when the borough would have the right to purchase its plant.

e. In the case of Wilson v, Rochester Borough, I 80 Pa, 509 (1897), the contract between the water company and the borough had apparently expired, yet the Supreme Court. following the cases of White v. Meadville and Metagcr v. Beaver Falls Borough, held that the borough of Rochester must be enjoined from constructing its own water works.

It is to be observed further, in this case, that the charter of the water company was granted after the Act of June 2, I887, P. L, 3 IO, which confers exclusive privileges upon gas light -companies only, and not upon water companies. It would seem to follow, then, that the Supreme Court has taken the broad position that a municipality has a right to supply itself and its inhabitants with water in one of two ways, either by erecting its own works, or by entering into a contract with ? private company; and that having adopted one or the other of such methods it has exhausted its power in that regard until such time as it can purchase the plant of the corporation with which it has contracted.

III. As to Gas Companies. The powers of municipalities may here be sub-divided as in the case of water companies:

(a.) Cities of the first class. The status of the gas works in Philadelphia is a matter of such recent history that no discussion of the same is needed. The abandonment by the city of the control of its own gas works and the leasing thereof to a private corporation is interesting as evincing a decided dissatisfaction, not only on the part of the municipal authorities, but of the public, with the system of municipal ownership, and the weight of evidence as gathered from the published statements from both sides would seem to be conclusive against the possibility of municipal control at a profit. 
(b.) Citics of the second class. The city of Pittsburg, so far as the City Digest shows, possesses no power to construct its own gas works either for public or commercial lighting, which functions have been exercised solely by private companies, subject to inspection by the City Gas Inspector under the provisions of the Act of April 28, I869, P. L. I242.

(c.) Cities of the third class. Their powers may be subdivided as in the case of water works into two classes:

I. Those in which the power to light the streets (no instance having come to my knowledge of any such city having attempted to furnish gas light to individuals) had been exercised by such cities while boroughs, under the general borough law of $185 \mathrm{I}$, or under the provisions of their special charters; and

2. Those conferred by the Act of May 23, I874, P. L. 230, and those conferred by the Act of May 23, 1889, P. L. 277 , which gave to such cities the following powers:

a. To provide for and regulate the lighting of the streets with gas, or electric lights, or light by other means ;

b. To have the cxclusive right at all times to supply the city with gas or other light, and such persons and corporations therein as may desire the same;

c. And also to have at all times the unrestricted right to erect and maintain the necessary buildings, machinery, etc., for that purpose ;

d. To contract with any person or company for lighting the city for a term not exceeding ten years;

e. To purchase, upon payment of proper compensation, the plant of any gas or electric light company in such city or adjacent thereto.

It would seem that wherever the privilege or franchise vested in any existing gas company was exclusive under its charter, whether special, or obtained under the General Corporation Act of April 29, I874, or wherever a city of the third class may have entered into a contract with such gas company for lighting its streets, the decisions of the Supreme Court relative to the rights of water companies as laid down in the above cited cases would apply, and that such city cannot 
erect its own gas plant until the expiration of twenty years from the date of the charter of such company.

(d.) Boroughs. The powers of boroughs are derived either from their special charters or from the general borough law of $185 \mathrm{I}$, as supplemented by the Act of April 16, 1875, P. L. 55 .

The Act of 185 I simply confers the power upon boroughs to light the streets, and not to furnish the inhabitants with gas, and the Act of 1875 likewise limits the application of the tax thereby authorized to be levied to the lighting of the streets, alleys, etc.

The cases above cited, relative to the powers of boroughs to erect their own water works, would seem to apply with equal force to the municipal ownership of gas plants where the franchises of existing companies are exclusive, or where any borough may have entered into a contract with an existing company to light its streets, and, therefore, no borough can erect its own plant without first purchasing the plant of the existing company.

A distinction, however, may be drawn between the powers of cities and boroughs to furnish water and to furnish gas, to wit: The several Acts of Assembly, above mentioned, authorize citivs to "supply the city with water and such persons, etc., as may desire the same," and authorize boroughs "to provide a supply of water for the use of the inhabitants;" that is to say: the supply of water for individuals is not separated from the supply of water for public purposes. On the other hand, the Acts of Assembly, above mentioned, relating to the supply of light, authorize both cities and boroughs " to provide for, and regulate the lighting of streets," or to "light the streets ;" and the Acts relating to cities confer by a separate section " the exclusive right at all times to supply the city with gas and such persons, etc., as may desire the same." In other words, the public function is distinct from the private function; and it may well be doubted whether the Supreme Court would hold that a municipality had surrendered its public duty by reason of its having entered into a contract with a private company for lighting the streets only. For the 
purpose of this article it is sufficient to say, that no contest has yet arisen upon this point between any municipality and a private gas company, so that the question is still open.

IV. As to Electric Light Companies. The powers of municipalities in this regard may again be sub-divided as before :

(a.) Cities of the first class. There appears to be no Act of Assembly conferring upon cities of the first class the power either to light its streets with electricity or to furnish electric lighting to its inhabitants.

(b.) Cities of the second class. The power to light its streets with electricity or to furnish electric lighting for commercial purposes appears thus far to have been withheld from cities of this class as well as from cities of the first class. (The city of Alleghany, now a city of the second class, established its own electric light plant while a city of the third class.)

(c.) Cities of the third class. The powers of cities of the third class in this regard are defined by the following Acts :

I. The Act of May 23, I874, which authorizes such cities "to provide for and regulate the lighting of the streets and the erection of lamp posts." (If this were the only power conferred it might be questioned whether it included the power to light the streets by electricity, which method was unknown at the time of the passage of the Act.)

2. The Act of May 23, I889, which confers the following powers :

a. To provide for and regulate the lighting of the streets with gas or electric lights or light by other means.

b. To have the exclusive right at all times to supply the city with gas or other light, and such persons or corporations therein as may desire the same.

c. And also to have at all times the unrestricted right to erect and maintain the necessary buildings, machinery, etc., for that purpose.

d. To contract with any person or company for lighting the city for a term not exceeding ten years.

e. To purchase upon payment of proper compensation the 
plant of any gas or electric light company in such city or adjacent thereto.

Although no exclusive privilege has ever been conferred upon any electric light company, it would seem, nevertheless, under the decisions of the Supreme Court in the cases of White v. Mcadville, Mctsger v. Beaver Falls Borough, and Wilson v. Rochester-Borough, above referred to, that wherever a city of the third class may have entered into a contract with an electric light company it cannot erect its own electric light plant without first purchasing the plant of such company.

The same distinction, however, suggested above as to the powers of municipalities with regard to the furnishing of water and the furnishing of gas may very properly be insisted upon with reference to their powers to erect their own electric light plants for street purposes. That is to say, the Act of 1889 above referred to seems to separate the function of lighting the streets from the function of supplying electric light for commercial purposes, and therefore no city should be deprived of its right to erect its own plant for the purpose of lighting its streets by reason of the fact of its having contracted with a private company for that purpose for a term of five or ten years as authorized by said Act.

(d.) Boroughs. The powers of boroughs with regard to electric lighting are conferred by the following Acts :

a. By the Act of June 16, I891, P. L. 302, the power to levy a lighting tax, which, by the Act. of April I6, I875, P. L. 55, was confined to a gas tax, is extended to the supplying of boroughs with electric light or other illuminant for the purpose of properly lighting the streets, etc., of the borough.

b. The Act of May 20, I89I, P. L. 90, confers upon all boroughs the right to manufacture electricity for commercial purposes for the supply and use of the inhabitants of said boroughs, provided that in all boroughs so desiring to furnish electric lights, where electric light companies already organized are furnishing electric lights to said borough or the public, the borough sicall endeavor to purchase the works of such corporation at a price to be agreed upon or fixed by viewers; 
and section three of said Act extends its provisions to all boroughs which had theretofore erected their own electric light plants.

Although no case has arisen, so far as I am able to find, defining the powers of boroughs under this Act, yet in view of the tenor of the decisions of the Supreme Court above referred to relating to municipal water works, it may fairly be argued that no borough may erect an electric light plant for commercial purposes without first purchasing the plant of the existing corporation to which it may have given permission to occupy its streets, especially where it may have entered into a contract with such corporation for lighting its streets. Here again, however, the distinction between the public function of lighting its streets and the private function of furnishing electric light for commercial purposes may perhaps be valid. If so, any borough under the powers conferred by the borough law of 1851 and the Act of April I6, I 875, P. L. 55, as amended by the Act of June 16,1891, P. L. 302, may erect its own electric light plant for the purpose of lighting. its streets without first purchasing the plant of the private corporation.

$V$. The powers above set forth are subject to a further and a very important limitation, viz.: that of ways and means. As no municipality can expend more in any one year than its current revenues will provide, which revenues cannot, except in rare instances, exceed three per centum of the assessed valuation of property subject to taxation, it follows that the expenditure required for the installation of either water works or a light plant, must be provided for by an increase of the indebtedness of the municipality.

The Constitution of 1874 , Article IX., Section 8, provides as follows: "The debt of any county, city, borough, township, school district, or other municipality or incorporated district, except as herein provided, shall never exceed seven per centum upon the assessed value of the taxable property therein, nor shall any such municipality or district incur any new debt, or increase its indebtedness to an amount exceeding two per centum upon such assessed valuation of property, without the assent of the electors thereof at a public election 
in such manner as shall be provided by law; but any city, the debt of which now exceeds seven per centum of such assessed valuation, may be authorized by law to increase the same three per centum, in the aggregate, at any one time, upon such valuation,"

It is apparent at a glance that two classes of municipalities are here provided for:

I. Those whose debt at the adoption of the Constitution was less than seyen per centum of their assessed valuation; and

2. Those cities whose debt at that time exceeded seven per centum of their assessed valuation.

In pursuance of this classification the legislature has passed Acts of Assembly appropriate to each class. Those relating to the first class are :

a. The Act of April 20, 1874, P. L. 65 , which provides:

I. For the increase of indebtedness by any municipality whose debt is less than two per centum of its valuation by a majority vote of its council or councils, subject to certain regulations as to notice of the intended increase, and provided that at the time of increasing the debt the ordinance shall provide for the levy of a tax equal to eight per centum of such increase.

In construing this portion of the Act the Supreme Court has several times decided that the two per centum limit applies to existing as well as new indebtedness, that is to say, if the proposed increase added to the existing indebtedness will exceed two per centum of the assessed valuation, then the municipal councils have no power to incur such increase; in other words, councils can only incur an indebtedness which, added to the existing indebtedness, will be less than two per centum.

2. For the increase, up to seven per centum, of the indebtedness of any municipality by an electoral vote (subject to the prescribed regulations as to notice of the intended increase) where the existing indebtedness already exceeds two per centum of the assessed valuation, or where the proposed increase added to the existing indebtedness will exceed such two per centum. In such cases, also, an annual tax equal to 
eight per centum of the proposed increase must be provided for by the ordinance authorizing such increase.

b. The Act of June 9, I89 I, P. L. 252, amends the Act of April 20, 1874, by requiring the purpose and amount of the increase to be stated upon the election tickets.

c. The Act of April i 8, I895, P. L. 36, amends the fourth section of the Act of April 20, I 874, by omitting the clause in the original Act relating to the requirements as to notice, publication, etc., and by further omitting the requirement that the tax levied shall be at least eight per centum of the increase. Under this Act the Supreme Court, in the case of Sener v. Euphrata Borough, i76 Pa. 80 (1896), decided that the omission of the clause relating to the requirements as to notice, etc., was not accidental, and that, as the amendment reads, no municipality could increase its indebtedness at any one time at any one election to an amount exceeding two per centum of the assessed valuation.

d. This construction of the Act of I 895 was so decidedly at variance with the letter and spirit of the constitutional provision above quoted, and of the Act of April 20, 1874, that the legislature at its next session, by the Act of May I I, 1897, P. L. 53, restored the clause relating to the requirements as to notice, etc., and expressly authorized an increase at an election to an amount not exceeding seven per centum of the assessed valuation, including existing indebtedness.

e. The Act of April 13, 1897, P. L. 17, amends the second section of the Act of April 20, I874, by omitting the requirement that the tax shall be equal to eight per centum of the amount of the increasc, so that at the present time, whether the debt be increased by vote of councils, or by electoral vote, the amount of the tax to be levied need only be sufficient for the payment of the interest and principal of the increase within thirty years from the date of the increase.

The Acts of the Assembly relating to the second class, contemplated by the constitution, are limited to cities of the first and third classes, which apparently are the only municipalities whose debts at the adoption of the constitution 
exceeded seven per centum of their assessed valuation, and are as follows :

a. By Section II of the Act of May 23, I874, councils of any city of the first class, whose debt exceeded seven per centum upon its assessed valuation, were authorized to increase such debt one per centum of such valuation, subject to certain regulations therein prescribed relating to notice of the proposed incrcase, and providing for the levy of an annual tax sufficient to pay the principal and interest of the debt within thirty years.

b. By the Act of June II, 1879 , P. L. I37, councils of cities of the first class were authorized to fund their floating indebtedness to the extent of ten million dollars, provided such loan should not exceed two per centum upon the assessed valuation of the taxable property of such cities.

The Supreme Court has three times passed upon the powers conferred by these Acts. The cases are as follows: Wheeler v. Philadelphia, $77 \mathrm{~Pa}$. 338 (1875), decided that the city of Philadelphia had the right under Section II of the Act of 1874 , above mentioned, to increase its indebtedness without any electoral vote to an amount not exceeding one per centum of its assessed valuation; Brooke v. Philadelplica, I62 Pa. I23 (I894), decided that in ascertaining the existing amount of indebtedness at any one time the amount already paid, or provided for in the sinking fund, should be deducted from the gross indebtedness, and that the debt might still be increased to the statutory limit; Pepper v. Philadelphia, I 8 I Pa. 566 (I 897), decided that inasmuch as the net indebtedness of the city of Philadelphia, after deducting from the gross indebtedness the amount provided for by the sinking fund, had fallen below seven per centum of the assessed valuation, therefore the city of Philadelphia is now in the same category with municipalities whose debt at the adoption of the constitution was less than seven per centum of their assessed valuation, and that no further increase of its indebtedness can be incurred without an electoral vote in the manner prescribed by the Act of April 20, 1874, and its several amendments above referred to. 
The practical effect of this last decision has been to retard the proposed loan for the improvement of the Philadelphia water works and other purposes.

c. By section 59 of the Act of May 23, I874, cities of the third class, whose debt at the adoption of the constitution exceeded seven per centum of their assessed valuation, were authorized to increase their indebtedness by vote of councils to an amount not exceeding three per centum of such assessed valuation, provided that such increase be made in the manner, and after the notice, and in accordance with every requirement necessary for the increase of indebtedness of cities of the first class under section I I of said Act.

The Act of May 23, I889, which now regulates the government of cities of the third class amends the Act of 1874 by requiring a two-thirds vote of councils for such increase of indebtedness.

Two or three cases have been decided by the Supreme Court construing the powers of cities of third class to increase their indebtedness, but have been confined rather to the question as to whether the contract proposed to be entered into would, or would not increase the indebtedness of the city: Erie City's Appeal, 91 Pa. 403 (1879); Black v. Chester, I75 Pa. IOI (1896); and Brown v. Corry, I75 Pa. 528 (1896).

The two cases of Brooke v. Philadelphia, and Pepper v. Philatelphia, apply with equal force to cities of the third class.

The questions, therefore, which every municipality desiring to establish a municipal plant for water or light must determine, are, according to the category within which such municipality falls :

I. Will the proposed increase raise the indebtedness above two per centum of the assessed valuation?

2. Will the proposed increase raise the indebtedness above seven per centum of the assessed valuation?

3. Will the proposed increase, added to prior increases exceed three per centum in the aggregate upon the assessed valuation?

From the foregoing review of the Acts of Assembly and the decisions of the Supreme Court it will be seen that the powers 
of municipalities in this state to erect their own plants, whether for water or for light, are much more limited than is popularly supposed, and that those municipalities which have already availed themselves of their powers in this regard, and are satisfied with the workings of their plants, are to be congratulated on having anticipated the decisions of the Supreme Court referred to in the earlier part of this article.

City Solicitor,

William D. Crocker.

Williamsport, $\mathrm{Pa}$. 